\title{
Analyzing the economic impact of sustainable development programs in the Brazilian Amazon
}

\author{
Analisando o impacto econômico dos programas de \\ desenvolvimento sustentável na Amazônia brasileira
}

DREW NELSON*

RESUMO: Nos últimos quarenta anos, a Amazônia brasileira tem sido objeto de muitos programas de desenvolvimento e industrialização. A grande maioria desses programas tem sido "megaprojetos" implementados pelo governo federal brasileiro. Recentemente, vários estados implementaram seu próprio estilo de programas de desenvolvimento econômico na Amazônia. Esses programas de desenvolvimento sustentável "locais" de menor escala oferecem aos formuladores de políticas uma alternativa aos "megaprojetos". Este artigo procura identificar os pontos fortes e fracos de cada modelo de desenvolvimento econômico. Além disso, este trabalho fornece uma análise de impacto econômico de um projeto de desenvolvimento sustentável "local", o Projeto Castanha-do-Brasil.

PALAVRAS-CHAVE: Programas de desenvolvimento econômico; desenvolvimento sustentável; Amazônia.

ABSTRACT: Over the last forty years, the Brazilian Amazon has been the object of many development and industrialization programs. The vast majority of those programs have been "mega-projects" implemented by the Brazilian federal government. Recently, several states have implemented their own style of economic development programs in the Amazon. These smaller scale "local" sustainable development programs offer policy makers an alternative to the "mega-projects". This paper seeks to identify the strengths and weaknesses of each economic development model. Additionally, this paper provides an economic impact analysis of one "local" sustainable development project, Projeto Castanha-do-Brasil.

KEYWORDS: Economic development programs; sustainable development; Amazonia. JEL Classification: Q01.

\footnotetext{
* Drew Nelson has two master degrees from the University of Texas at Austin, one in Public Policy and the other in Latin American Studies, Austin/Texas, USA. Submitted: January 2003; accepted: April 2003.
} 
The Brazilian Amazonian rainforest is being developed an unprecedented rate. ${ }^{1}$ Deforestation and infrastructure projects focused on the Amazon continue, even as international environmental and social pressures against them increase. However, within Brazil, the Amazon is a focus for economic development. The Brazilian policy debate, until the 1970's, was not traditionally centered on whether the Amazon should be developed, but rather, how big the development projects should be.

Until the 1970's, the economic development strategy that the Brazilian government adopted for the Amazon was growth through large-scale infrastructure projects. Projects such as roads, dams, and power plants dominated the development agenda for the Brazilian Amazon. The belief was that if the government created infrastructure in the region, industrialization would shortly follow. ${ }^{2}$ Since the 1970 's there has been an internal policy debate as to what strategy should be implemented in order to develop the Amazon. This debate has pitted environmentalists, Indian-rights activists, and scientists against miners, developers and industrialists. The policy debate has resulted in the halting of the full-fledged drive to develop the Amazon, however there is still great internal pressure to continue the trend of "mega-projects".

"Mega-projects" have been the traditional method for Amazonian development; but over the last several years, smaller-scale "local" sustainable development projects run by states have become an accepted means of economic development as well. These programs seek to produce sustainable economic growth by focusing on projects that require less initial capital, but produce economic gains and preserve the natural resources that make the Amazon a unique place. The sustainable development projects seek to place a higher value on local production and goods.

The presence of a relatively new economic development strategy in the Amazon raises the question; is sustainable development effective in terms of providing longterm economic growth for the Brazilian Amazon? Can sustainable development projects supplant mega-projects as a way to bring economic development to the Amazon? This paper will provide examples of sustainable development projects in the Brazilian Amazon and will attempt to determine the economic impact of one project in particular, Projeto Castanha-do-Brasil. The paper is divided into four sections; definition of a sustainable development framework, advantages and disadvantages of sustainable development, description and economic impact of Projeto Castanha-do-Brasil, and the conclusion.

\footnotetext{
${ }^{1}$ Laurence, William. “The Future of the Brazilian Amazon.” Science Magazine. Online. Available: http:// www.sciencemag.org/cgi/content/full/2915503438 ? sendit. $y=7 \&$ sendit. $\mathrm{x}=64 \& \mathrm{gca}=291 \% 2 \mathrm{~F} 550$ $3 \% 2 \mathrm{~F} 438 \&$.

${ }^{2}$ Cardoso, Fernando Henrique and Müller, Geraldo. Amazônia: Expansão do Capitalismo. São Paulo. Editora Brasilense, 1977.
} 


\section{DEFINITION OF A SUSTAINABLE DEVELOPMENT ANALYTICAL FRAMEWORK}

Central to the question of economic development in the Amazon is the issue of whether economic development is the responsibility of the state. Historically the state has provided economic growth because it is in its own interests to have a larger economy. More development means increased wealth, which translates into higher tax revenue. Traditionally the state has the responsibility to provide economic development because it is often the only institution within a country that has the resources to do so. In the case of the Brazilian Amazon, only the federal government had the resources and desire to bring about economic growth in the region. In the Amazon, Brazil embraced Marshall's theories of income distribution and sought to improve the social position of its citizens through economic development programs.

Developing countries seek to expand the size of their economies and achieve convergence with the developing world, and as long as that is a policy, governments will seek to create more economic opportunities for its citizens. Economic development programs sponsored by the government attempt to increase wealth while also increasing social inclusion, private initiatives make less of an effort to do so. Therefore, the responsibility of economic development falls on the state, if it wishes to guarantee that economic gains resulting from the project are enjoyed by the greatest number of people.

The state should be responsible for providing economic development, but how should it do so, and how can those projects be analyzed? Over the last decade, large mega-projects which have profound negative impacts on the Amazon, have begun to be supplanted by sustainable economic development projects. Luis E. Aragón in his book, The Amazon as a Study Object, recognizes that only after the UN conference on Human Environment in Stockholm (1972) were "established concepts of development based on economic growth at any cost" challenged. ${ }^{3}$ The 1972 conference leads to a revision of some development frameworks to include sustainability and environmental issues.

In his book, Aragón provides a "reformulation of the concept of development" which "must consider simultaneously [...] five dimensions of sustainability" in order for sustainable growth to occur. ${ }^{4}$ At its core sustainable development seeks to find ways to secure economic growth while at the same time protecting the world's environment. ${ }^{5}$ According to Aragón, the five dimensions of sustainability are:

\footnotetext{
${ }^{3}$ Aragón, Luis E. The Amazon as a Study Object. Stockholm. Institute of Latin American Studies Stockholm University, 1994.

${ }^{4}$ Ibid.

${ }^{5}$ Sachs, Ignacy. Caminhos para o Desenvolvimento Sustentável. Editora Garamond, Rio de Janeiro, 2002.
} 
1) Social,

2) Economic,

3) Ecological,

4) Spatial, and

5) Cultural sustainability

Social sustainability refers "principally to the question of whom development is for [and] who are the beneficiaries of the program". Economic sustainability shifts the economic paradigm to argue, "social, environmental and human benefits should be the center of economics". Ecological sustainability asserts, "development and environmental preservation are two faces of the same coin that should be seen as complementary, rather than contradictory". Spatial sustainability refers to the economic discrepancies of North and South and urban versus poor suggesting, "disparities between regions should be reduced". Cultural sustainability "means recognition of the importance of local cultures and endogenous ways towards modernity" asserting "development can not be imposed by outside forces, but should instead grow from within". ${ }^{6}$

The framework provided by Aragón allows for sustainable development projects to be comparatively analyzed. In order to determine the economic impacts of sustainable development projects, a definition of sustainability must be provided, and Aragón's framework provides that definition. Aragón's five dimensions of sustainability are a framework to "reformulate" the existing model of economic development. As Projeto Castanha-do-Brasil embraces sustainability and economic development; Aragón's theory is applicable in terms of topical pertinence, but does it fulfill the criteria for frameworks as defined by Paul Sabatier?

In Theories of the Policy Process, Paul Sabatier outlines four criteria that help to develop strong analytical frameworks. The four criteria are that the framework should: "do a reasonably good job of meeting the criteria of a scientific theory"; "be the subject of a fair amount of recent conceptual development [...] a number of currently active policy scholars must view it as [...] viable"; be a "positive theory seeking to explain much of the policy process"; and "address the broad sets of factors that political scientists [...] have traditionally deemed important". ${ }^{7}$ Does Aragón's framework meet these criteria?

In the case of the first criterion, which stipulates that the framework be clear, broad based, and consistent, the answer is yes. Aragón's framework touches on many factors that would influence the final policy decision. The factors he defines are clearly explained and are easy to understand. The factors can also be used to frame any decision that incorporates economic decisions, so it is applicable to a variety of policy processes in a variety of political systems.

\footnotetext{
${ }^{6}$ Ibid.

${ }^{7}$ Sabatier, Paul. Theories of the Policy Process. Davis, California. Westview Press, 1999.
} 
Sabatier's second criterion is more problematic to apply to Aragón's framework. There is no dearth of literature devoted to economic development and the environment. However, the author is not aware of any specific scholars that have adopted this framework for their analysis of development issues, nor is the author aware of any specific empirical testing that this specific framework has undergone. Yet, the five dimensions of sustainability Aragón outlines appear in a large amount of scholarly work devoted to economic development in environmentally sensitive areas. Therefore, while the actual framework may not receive much scholarly attention, the ideas behind it do, thus qualifying the framework to meet the second criterion.

The third and fourth criteria explain the policy process and address political decisions. These areas are perhaps where Aragón's framework is the strongest. It seeks to ask question such as: who is this program for, and who benefits from it; how will this program impact the economics and environment of the area; why the area needs to be developed; who is for/against that development; and what effects that development will have on the culture of the area. These questions are at the heart of the policy process and help explain why certain political decisions are made.

This paper is not designed to defend the rigidity of Aragón's framework, and undoubtedly there are still many unanswered questions surrounding it. However, the framework superficially meets Sabatier's criteria, which for the purposes of this paper is all that is necessary. Aragón's framework allows the sustainable development economic model to be simplified in order to be analyzed. The most important test, which Aragón's framework passes easily, is the fact that it is useful in terms of defining sustainable development.

\section{ADVANTAGES AND DISADVANTAGES OF THE DEVELOPMENT MODELS}

As the paper seeks to identify whether sustainable development projects are a policy that should be pursued by governments instead of mega-projects, sustainable development must be explained with a list of advantages and disadvantages. In order to better understand the advantages and disadvantages of sustainable development, it must be compared to its alternative, mega-projects. The mega-project model has dominated Brazil since the country began to develop and as such, is more prevalent, and therefore it shall be analyzed first.

Since colonial times, Brazilians viewed the Amazon as an inexhaustible area that could provide great wealth could it ever truly be developed. ${ }^{8}$ The rubber boom only underscored this notion as Manaus, a city in the heart of the Amazon, became one of the richest cities in the world solely due to its ability to extract natural resources from the forest. Successive governments created many projects that attempted to develop the Amazon for economic and national security reasons. The vastness of the

\footnotetext{
${ }^{8}$ Cardoso, Fernando Henrique and Müller, Geraldo. Amazônia: Expansão do Capitalismo. São Paulo. Editora Brasilense, 1977.
} 
Amazon was seen as security hazard, and as such, the military government designed and implemented projects that attempted to reduce the scale of the Amazon. ${ }^{9}$ Chief among these projects was the Trans-Amazonian highway, which served to link two ends of the Amazon and bring more development to the region by attracting workers. ${ }^{10}$ Democratic governments have since adopted the military's strategy of creating large-scale, or mega-projects. Ironically enough, aspects of President Fernando Henrique Cardoso's Avança Brasil program maintain this tradition, even though in 1977 then academic Fernando Henrique wrote a scathing analysis of the military government's policy of Amazonian development through building roads.

Avança Brasil is a federal, multi-billion dollar development initiative, being implemented throughout the country. The Avança Brasil projects slated for the Amazon continue in the mega-project tradition. These projects have budgets that approach and surpass the billion-dollar category and are designed for the express purpose of creating infrastructure that will facilitate the industrialization of the Amazon. One advantage of mega-projects is their sheer size. A large-scale project creates more jobs, requires more materials and affects more people, thus providing an initial direct capital injection into the region where the project is being built. The scope of these projects is usually immense as well; they are designed to develop vast regions, not tiny parcels of land. The large scope allows for a minimum amount of projects to project huge economic changes upon a region. Additionally, mega-projects provide an opportunity for Brazil to receive large influxes of foreign investment as the large scale of the projects readily attracts foreign money.

Unfortunately, mega-projects have many disadvantages as well. The designs and structure of the development program usually emanate from the federal government. Therefore, the designs often reflect values that are not native to the area being developed. Local "best practices" are routinely ignored for grander visions, when often times those local ideas could provide tremendous benefits to the federal program. The large scale of the federal program frequently precludes the local solutions from being incorporated. Critics assert that this has negative repercussions on the target populations; by delivering economic gains but degrading the social position, megaprojects only make the population more dependant on the state for continued economic growth (Chart 1). Additionally, mega-projects depend on a large amount of capital, which could result in Brazil increasing its already large foreign debt.

Perhaps the most devastating disadvantage of the mega-projects is the way in which they contribute towards environmental degradation. During golden age of the mega-projects (1950-1970), the thinking was that economic growth and environmental protection could not co-exist, and that developing countries would begin to protect the environment when they converged with the developed world. ${ }^{11}$ There is no doubt that the projects provide economic growth, but at what cost to the

\footnotetext{
${ }^{9}$ Ibid.

${ }^{10}$ Ibid.

${ }^{11}$ Sachs, Ignacy. Caminhos para o Desenvolvimento Sustentável. Editora Garamond, Rio de Janeiro, 2002.
} 
environment? The trans-Amazonian highway opened up large sections of the Amazon to development, but was a catalyst for deforestation and trade in endangered species. Another disadvantage of mega-projects as in the case of the TransAmazonian highway is that the projects often do not make economic sense, but serve only to further political agendas. ${ }^{12}$

The sheer size of the mega-projects represents two other potent disadvantages - unsustainability and large costs. Dams, roads, and power plants provide economic gains, but require tremendous inflows of capital. Eventually this capital evaporates and the project suffers. The workers that move to the Amazon to build the projects will soon move away if they have no jobs after construction is completed. Even if the required level of job replacement is maintained, mega-projects still have relatively short life spans in the Amazon. The jungle, if not irrevocably harmed, will eventually reclaim highways and the river will eventually silt over dams built upon it. These processes unfold over decades, even centuries, but are spending billions of dollars on a venture that could be useless in a lifetime, a sound investment?

The question posed above is the greatest advantage of the small-scale state local projects. These projects provide economic growth through using resources within the Amazon that have existed for millennia. If managed properly, those resources, which are native to the Amazon, can last several millennia more. By using existing resources in the Amazon, the local projects protect the environment as well. Residents know that the forest can provide wealth and are less inclined to participate in "environmentally unfriendly" behavior such as deforestation. Local projects' small scale allows their focus to be directed at very specific groups, illustrating another example of the small-scale project's advantages. If a group of people lives or works in a particular area that is need of economic development, a specific project aimed to improve their economic situation can be created relatively cheaply and easily.

Brazil, and the other developing tropical countries could have a tremendous advantage if they fully embrace sustainability. These countries could become "exporters of sustainability" transforming environmental challenges into economic opportunities. ${ }^{13}$ Tropical countries can use their extensive rainforests as credits for industrial pollution in the developed world. Additionally, tropical forests could hold many potential economic opportunities that would allow developing countries to "skip development phases" and close the gap with developed countries. ${ }^{14}$ However, for this to happen, economists must change the way the think about economic development. Sustainable development brings about lower growth in the short term,

\footnotetext{
${ }^{12}$ Cardoso, Fernando Henrique and Müller, Geraldo. Amazônia: Expansão do Capitalismo. São Paulo. Editora Brasilense, 1977.

${ }^{13}$ Sachs, Ignacy. Caminhos para o Desenvolvimento Sustentável. Editora Garamond, Rio de Janeiro, 2002 .

${ }^{14}$ Ibid.
} 
but in the long term provides more growth and a large tax base, but economists usually think in terms of decades instead of centuries. ${ }^{15}$

Unfortunately, sustainable development projects have many disadvantages as well. Some critics maintain that the while the projects are successful in building citizenship, they are not successful in providing economic growth. These critics argue that this process only serves to alienate the target population by promising, but not delivering, tangible economic growth (Chart 1). With no real economic growth, the local-driven economic programs are nothing more than social programs. If the goal is long-term sustainability and project "buy-in" of a population, than lack of true economic growth is a considerable disadvantage of local programs.

Two disadvantages of small-scale projects that are interlaced are their small scale and the number of projects necessary to produce a noticeable regional increase in economic growth. Managing scores of small projects requires an increased bureaucracy, which is not encouraged by the international lending community. Several smallscale projects could create economic wealth, but as the projects expand and other projects enter the market, the economic benefits will decrease. Market phenomena require that few of the projects have overlapping economic benefits complicating an Amazon-wide small-scale development undertaking. For example the first sustainable development project that seeks to sell artisan baskets made by Amazonian tribes will probably bring about economic growth to that tribe. However, as the program expands to reach other tribes, they will increase the supply of the basket, and take market share away from the original project thereby limiting the economic gains of the original project. The solution is to develop similar projects with a variety of goods which creates a need for some central planning, which is not a viable option in today's economy.

Chart $1^{16}$

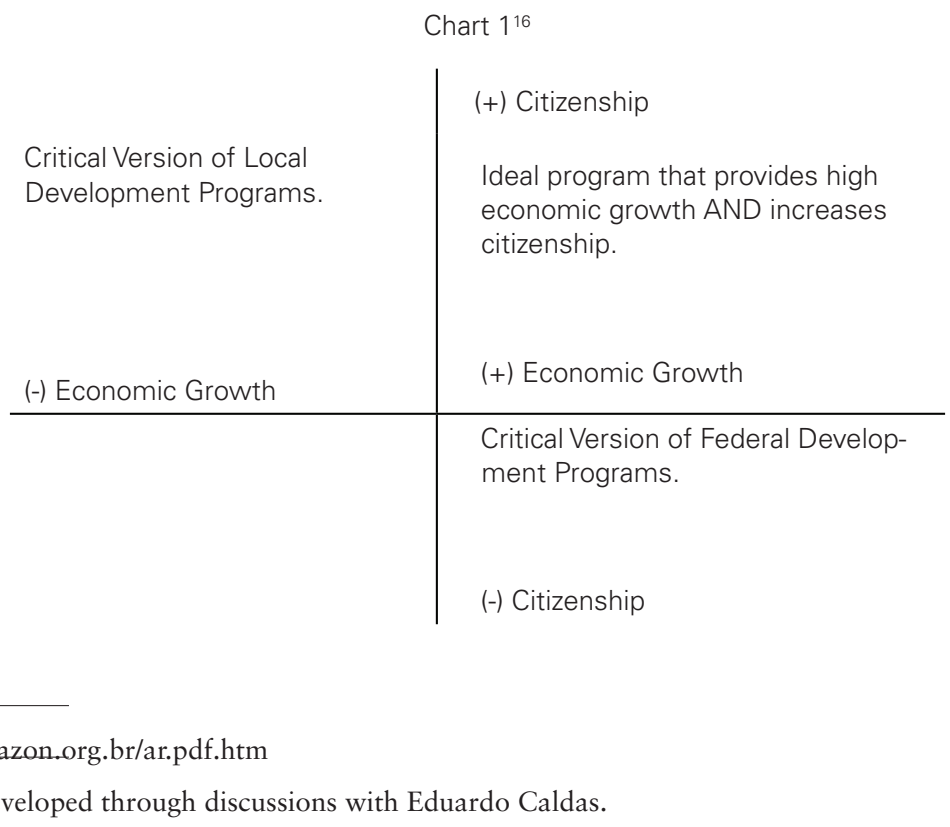

15 www.imazon.org.br/ar.pdf.htm

${ }^{16}$ Chart developed through discussions with Eduardo Caldas. 
Chart one illustrates the ideal outcome of economic development programs in the Amazon, programs that provide both increased citizenship and economic growth. Analysis of Projeto Castanha-do-Brasil will show whether the sustainable development model supercedes the vision outlined by critics and reaches the "ideal" quadrant of the graph.

\section{DESCRIPTION AND ECONOMIC IMPACT ASSESSMENT OF PROJETO CASTANHA-DO-BRASIL}

Since the Eco-92 conference held in Rio, sustainable development has gained acceptance across the globe as a means to provide economic development while at the same time protecting the environment. Brazil has flirted with many sorts of sustainable development projects in the Amazon that go beyond the creation of reserves, but most of these projects have been initiated and run by either state governments or NGO's. All of the small Amazonian states; Acre, Amapá, Rondônia, and Roraima have experimented with small-scale extractivist development projects.

One example, which all of these sates participate in, is international wood certification programs. Wood Certification programs are based upon a simple premise, that consumers in developed markets will pay more for lumber that is certified as sustainable and ecologically sound. Lumber receiving certification is guaranteed to be extracted in a way that is ecologically sound. Certified Amazonian wood can sell for higher prices on the international market, encouraging the sustainable management of the world's tropical forests. As residents of the Amazon realize they can sell certified wood for more money, harmful environmental practices no longer make economic sense, as residents realize that environmentally sound lumber is worth more than wood derived from careless deforestation.

Studies have shown that due to average annual rainfall levels, only $17 \%$ of the Amazon has a chance for economic success through agriculture and ranching. ${ }^{17}$ That leaves $83 \%$ of the Amazon whose greatest chance for economic success is through "sustainable forest management". ${ }^{18}$ However, sustainable development cannot take place in an economic environment which is left wholly to market forces. ${ }^{19}$ With market forces acting freely, land-use in this $83 \%$ of the forest will be based on predatory logging, creating a boom and bust economic cycle. ${ }^{20}$ Predatory logging creates rapid growth, but as prime trees are logged, growth becomes unsustainable and rapid growth is followed by a precipitous drop-off in profits and

\footnotetext{
${ }^{17}$ www.imazon.org.br/ar.pdf.htm.

18 Ibid.

19 Sachs, Ignacy. Caminhos para o Desenvolvimento Sustentável. Editora Garamond, Rio de Janeiro, 2002.

${ }^{20}$ www.imazon.org.br/ar.pdf.htm.
} 
employment, leading to an unstable economy and tax base. This cycle is known as boom and bust, and is due to the fact that economic growth could not be sustained. Enacting sustainable logging habits decreases the initial growth that is found in predatory situations, but jobs and profits remain constant long after the drop-off would have occurred creating a stable economy, a stable work environment, and a stable tax base. ${ }^{21}$

Each state has attempted its own sustainable development models, which seek to end the boom and bust cycle of predatory economic practices. Acre, a state situated on the Brazil's western border with Bolivia is mostly covered by rainforest. Like all of the Amazonian states, it is poor and has attempted several programs to bring economic development to the area. One of the most successful programs is the Reserva Extrativista do Alto Juruá which sets aside a large region in the eastern reaches of the state as an ecological reserve designed to produce sustainable economic growth.

The rapid industrialization of the world, and its driving need for rubber, brought huge amounts of "northeasterners" looking for an escape from the rural poverty of Northeastern Brazil to the Amazonian rainforests in order to extract sap from the rubber trees. Known as seringueiros, these workers and their families stayed in the forest long after the international price of rubber collapsed and the dream of immediate wealth in the rainforest was destroyed. Today, these families still live throughout the Amazon forest and make their living through extractavist activities.

The Reserva Extrativista do Alto Juruá has an area of 5,062 square kilometers and 6,000 inhabitants, $75 \%$ of whom are seringueros. ${ }^{22}$ The project is a joint venture with the Secretary of Planning for the State of Acre and the National Bank of Social and Economic Development (BNDES). The main pillars of the project are improved transportation, the formation of cooperatives, construction of warehousing facilities, and commercialization of rubber.

Rondônia is a southern neighbor of Acre and shares the same geography and economic situation. It too has created an ecological reserve as a means to create sustainable economic development. The reserve, Reserva Extrativista do Rio Ouro Preto, is located along the Bolivian border and encompasses 204,583 hectares. ${ }^{23}$ The inhabitants are also dependant on rubber collection, and Rondônia's program mirrors that of Acre in its attempt to facilitate the transportation of the latex to market and increase its value.

Roraima is Brazil's northern-most state and shares a long border with Venezuela. It has a large indigenous population who reside mainly in the southern parts of the state. That state created an economic development program that fused traditional methods of creating clothing from plant fibers and modern technology. The

\footnotetext{
${ }^{21}$ Ibid.

${ }^{22}$ Arnt, Ricardo. O Destino da Floresta. Rio de Janeiro. Dumará Distribuidora de Publicações, 1994.

${ }^{23}$ Ibid.
} 
indigenous populations produce swathes of material from plants according to their tradition. The material is then sent to France where it is chemically treated to create a material similar to leather, and then returned to the indigenous community. Upon its return, the indigenous population makes purses, pants, and belts that are then sold on the national and international markets.

The Brazilian state of Amapá, located in the far northeastern corner of the country is one of the smallest states in Brazil, not only in size, but also in terms of population and economic activity. It also provides the best example of small-scale local sustainable development projects in Brazil. The Amazon rainforest comprises a large part of the state's territory and has made settlement difficult. This, coupled with Amapás distance from Brasília, Rio, and São Paulo and Amapás large border with French Guiana, has lead to a growing sense that Amapá is an isolated outpost within the vast Brazilian territory. Amapá's former left-leaning governor, João Alberto Capiberibe, repeatedly stated that he and the citizens of his state often feel closer to Paris than to Brasília. Capiberibe's statement might have some political truth to it, but in economic terms Amapá is far short of France and its industrialized economy. Economic indicators in Amapá reflect poverty and social exclusion for large segments of the population, especially those who make their living by extracting resources from the forest. In Amapá, the richness of its forests contrasts deeply with the poverty of its inhabitants. ${ }^{24}$

Prior to the nineteenth century, the population of Amapá was mostly indigenous. Southern Amapá now has a large population of seringueros who have since found other goods to extract. In the south of Amapá, this means collecting and selling castanhas (brazil nuts). The brazil nut gatherers, known as castanheiros, live almost exclusively on the money they receive from selling the brazil nuts. The economic situation of the castanheiros is one of extreme poverty exacerbated by the way that the nuts move from the forest to world markets. Most castanheiros rely on a middleman to finance the nut harvest and to buy and transport the nuts to markets. The middleman supplies all the tools, equipment, and even basic foodstuffs necessary to nut collection at an inflated price and buys the harvest at a deflated price. This practice has existed for decades, if not centuries, and has evolved only to further indebt the castanheiros. ${ }^{25}$ The castanheiros rapidly enter into vicious cycle of debt that soon becomes a form of white slavery.

There is a local government sponsored response to the problem of poverty and social exclusion of the castanheiros. The State Government of Amapá developed a program, Projeto Castanha-do-Brasil, which seeks to create co-ops of castanheiros in order to provide market value for the nuts while at the same time ending the

\footnotetext{
${ }^{24}$ Field Research, for more information: Fujiwara, Luis and Nelson, Drew in 20 Experiências de Gestão Pública e Cidadania, Ciclo de Premiação 2001. Organized by Helio Batista Barboza and Peter Spink. Programa Gestão Pública e Cidadania, São Paulo, 2002.

${ }^{25}$ Cardoso, Fernando Henrique and Müller, Geraldo. Amazônia: Expansão do Capitalismo. São Paulo. Editora Brasilense, 1977.
} 
necessity of middlemen to distribute the nuts. The program also developed ways by which the value of the brazil nut is increased through verticalization of the product; creating soaps, oils, ice creams, and other by-products, bringing a greater aggregate value to the nuts. ${ }^{26}$ By means of the Projeto Castanha-do-Brasil, the government has not only increased income levels of the castanheiros, but has stimulated civic involvement, increased sustainable use of the state's natural resources, and decreased social exclusion. The results have been a complete inversion of the production logic in the south of Amapá, breaking the cycle of dependency on middlemen, and ending the belief that only mega-projects can provide economic development to the Amazon.

The Projeto Castanha-do-Brasil was created in January of 1995 with the specific goals of: generating employment and wage increases, valorizing native forest products, combating poverty, ending rural exodus, and increasing the citizenship of people native to the Amazon. In its incipient stage, the program was nothing more than a political promise made into a reality, and provided no benefits other than a guaranteed source of income from the state. Capiberibe quickly set out to change this. The program was incorporated into a broader governmental program, which had the resources and experience in promoting sustainable development programs. Since its creation in 1995, the Program for Sustainable Development of the State of Amapá (PDSA) has been responsible for all sustainable development programs in Amapá. Through PDSA's guidance, the castanheiros began to organize themselves into co-ops.

Co-ops form one of the main pillars of the Projeto Castanha-do-Brasil. Through the co-ops, the castanheiros not only get market value for their brazil nuts, but the co-ops actively seek to verticalize the production of Brazil nuts. ${ }^{27}$ Instead of merely selling nuts in the shell, the co-ops sell nuts that have been deshelled, dehydrated, and packaged to be exported. In addition, the co-op also produces Brazil nut flour, Brazil nut cookies, and Brazil nut oil. Product verticalization brings higher wages to the co-op members who start a virtuous cycle of increased wages, increased investment in the co-ops, and increased production and increased wages. Even castanheiros who are not affiliated with the co-ops benefit from the co-ops as they can sell their nuts to the co-ops and get better prices than if they sold to the middle men.

The other main pillar is the state run research center, Institute for Studies and Investigation (IEPA). IEPA has been charged with researching the medicinal and scientific values of the brazil nut in order to bring about greater product verticalization for Amazonian products. ${ }^{28}$ Through their research, Brazil nut oil has been extensively tested and proven to have properties useful in cosmetic manufacturing.

\footnotetext{
${ }^{26}$ Alessio, Nelson Luiz Nouvel. "Projeto Castanha: desenvolvimento sustentável com geração de renda para os castanheiros do Sul do Estado do Amapá”. In Redução da Pobreza e Dinâmicas Locais. Ilka Camarotti e Peter Spink (orgs.). Rio de Janeiro, Editora FGV, 2001.

${ }^{27}$ Leonelli, Domingos. Uma Sustentável Revolução na Floresta. São Paulo. Editora Viramundo, 2000.

${ }^{28}$ Kitamura, Paulo Choji. “Amazônia: produtos e serviços naturais e as perspectivas para o desenvolvimento
} 
IEPA's research led to Brazil nut oil soaps, hydrating creams, and shampoos produced by a French firm which then sells the cosmetics to the European market. IEPA's research also produced the ideal chemical recipe for the brazil nuts cookies which would minimize the oil while retaining taste.

Projeto Castanha-do-Brasil is not just about economics and increasing wages; there is a strong commitment to building citizenship and increasing public participation for people previously excluded from the process. The two main co-ops COMARU and COMAJA fill two different rolls but the work they do is complimentary. COMARU dehydrates and packages the nuts for exportation, and COMAJA turns the nuts into flour and converts the flour into cookies which are then sold to state schools for school lunch programs. Yet their different functions do not preclude them from having the same result of increased public participation. As this is a state initiative it is easy to think that the state would have a large say in the operations of both co-ops, but in fact both co-ops are highly independent and are accountable only to their members. The state has not replaced the middlemen as a controlling force as some feared would happen. Co-op members, due to their participation and ownership, now have control over where they sell their products and how the co-op will grow. ${ }^{29}$

The co-ops, and the government's commitment to them, have inversed the priorities of industrialization and economics in southern Amapá. COMAJA provides a perfect example of the new system. Previously, the forest existed only to provide purely extravication activities, and was home to people living in poverty. Now, through COMAJA there is small scale industrialization in certain areas.

The program inverts more than just economic priorities; it inverts social ones as well. As the co-ops are social institutions, they help create and maintain social capital in the areas where the co-op members are active. This social capital led to electrification of the community surrounding COMARU's urban factory. The co-op also organized efforts to pave the streets in the area, no small task for an outlaying urban area in one of the poorest urban municipalities in Brazil. Undoubtedly, social capital factors of the program have lead to more aware and active citizenship.

Projeto Castanha-do-Brasil inverts gender roles as well. For example, a COMAJA cookie factory is mainly employed with women. Before their employment at the factory these women faced the burden of having to gather the nuts in the forest, far away from home. One woman credited the factory for saving her life by creating a work environment that was close to home, safe, and not physically exhausting. Women have active roles in the co-ops and in the co-ops' administrative

sustentável regional”. In Economia do Meio Ambiente: teoria, políticas e gestão de espaços regionais. Ademar Ribeiro Romeiro, Bastiaan Philip Reydon e Maria Lúcia Azevedo Leonardi (orgs.).

${ }^{29}$ Alessio, Nelson Luiz Nouvel. "Projeto Castanha: desenvolvimento sustentável com geração de renda para os castanheiros do Sul do Estado do Amapá”. In Redução da Pobreza e Dinâmicas Locais. Ilka Camarotti e Peter Spink (orgs.). Rio de Janeiro, Editora FGV, 2001. 
structure, providing a rare opportunity for women in rural Amazon to interact as equal business partners with males.

Another important citizenship benefit of the program is the "right to stay" that it helps entrench. Many inhabitants of the forest prefer a life there, than to one in an urban setting. Yet, due to economic reasons, they must emigrate to the city in order to make enough money to survive. Life in the city may provide more "modern" conveniences like continuous electricity, running and wastewater systems, and convenient access to social services, but rarely do these emigrants escape from the bottom rungs of the urban poor. Projeto Castanha-do-Brasil allows people to stay where they prefer to live and still make enough money to survive. This saves money for the state in the long run as there is less of a need for social programs for the urban poor.

The environmental benefits of Projeto Castanha-do-Brasil are enormous. By making forest resources sustainable providers of wealth, there is more incentive to protect the rainforest. Inhabitants are more likely to report illegal logging, as those loggers might be cutting down trees that contribute to people's livelihood. ${ }^{30}$ Additionally.

There are many valid criticisms of the project. The strongest critique is the active role the state plays in the project's activities. The state was the original financer of the program and the original purchaser of the brazil nuts. Towards the beginning of the project, Amapá bought close to $100 \%$ of the co-op's production. The state is still the largest client, but for the first time (summer of 2001) is projected to provide less than $50 \%$ of the co-op's revenue. The obvious concern behind the state's active economic role is the sustainability of the project. If there were a new administration that decided to buy fewer, or no nuts at all, it could dramatically damage the co-op's ability to stay solvent.

Another critique is that while the economic gains of the project have been substantial, they are not near the levels theoretically attainable by mega-projects. Megaprojects bring investment in billions of dollars, while in comparison, smallscale projects spending is a drop in the bucket.

The development issues explained above are complicated and quite different from other economic development programs in Brazil. Therefore it would be difficult to compare models unless the same framework is used to analyze both economic development models. The same framework used to analyze the transportation corridors of Avança Brasil must be used to analyze Projeto Castanha-do-Brasil. How does Projeto Castanha-do-Brasil meet Aragón's framework of sustainability?

Projeto Castanha-do-Brasil meets the first factor of social sustainability. Social sustainability, according to Aragón, "means that the process of development should be centered on the well-being of man". ${ }^{31}$ This project definitively improves the well being of the people involved with it through economic and citizenship advances. It

\footnotetext{
${ }^{30}$ Leonelli, Domingos. Uma Sustentável Revolução na Floresta. São Paulo. Editora Viramundo, 2000.

${ }^{31}$ Aragón, Luis E. The Amazon as a Study O bject. Stockholm. Institute of Latin American Studies Stockholm University, 1994.
} 
achieves this improvement of well being in a way that reduces the gap between the rich and the poor, which is another stipulation of the criterion.

Projeto Castanha-do-Brasil meets the second criterion, economic sustainability, as well. Aragón argues for the consideration of social, environmental, and human benefits in economic decisions. The economic growth derived from the project improves citizenship and builds social capital, therefore meeting the social requirement. Using resources from the rainforest in a sustainable way is environmentally friendly, satisfying that requirement. The human benefits of the program come in the form of not only not having to be displaced by the project, but beyond that, the human benefits manifest themselves by granting the "right to stay" in a traditional area of residence to the program participants. Thus, the program meets Aragón's second criterion. However, it is important to note that long-term sustainability might be doubtful if the state does not further reduce its economic ties to the program.

In Aragón's framework, ecological sustainability, the third criterion, advocates "intensifying the use of natural resources with minimum damage to ecosystems" and viewing "development and environmental preservation [...] [as] two faces of the same coin". ${ }^{32}$ There is no extractivist model of development that does more to using natural resources with minimum damage. Not only are the Brazil nuts harvested in a sustainable manner, but the co-op brings product verticalization so each nut renders more profit than it did previously. This strategy brings development and environmental preservation. This is the criterion that Projeto Castanha-do-Brasil excels at.

The fourth criterion, spatial sustainability, argues for programs that reduce poverty on the North/South axis and along the urban/rural axis. North/South issues are beyond the realm of this initiative, but urban/rural wealth discrepancies are not. There is no doubt that because of the co-op's actions the wealth of those who live in remote areas of the rainforest now gain more than they did under the middleman system. Projeto Castanha-do-Brasil is directly responsible for increasing income in certain rural areas of the state.

The final criterion is cultural sustainability, which Aragón defines as "recognizing local cultures and endogenous ways..." 33 Those who form the co-op worked as Brazil nut gathers long before the co-op was formed. The co-ops provide them with an opportunity to continue with that lifestyle and not have to immigrate to urban areas in search of higher wages. The program is culturally sustainable because it is using local traditions as a means of economic development instead of importing a solution that may not follow best practices.

Projeto Castanha-do-Brasil meets all five of Aragón's criterion; some criteria are met more handily than others, but they are still met. This leads to the conclusion that Projeto Castanha-do-Brasil as it stands today is in fact a viable alternative for sustainable economic growth in the Amazon as defined by Aragón. However, if the state does not continue the process of divesting from the project, its longterm sustainability and its ability to fit this framework is questionable.

\footnotetext{
${ }^{32}$ Ibid.

${ }^{33}$ Ibid.
} 


\section{CONCLUSION}

The policy debate around the Amazon has shifted in the last thirty years.

Whereas previously the policy debate focused exclusively on how to develop the Amazon, since then, more emphasis has been placed on the importance of protecting the Amazon's rich ecosystems. This process has resulted in two divergent development strategies, those that focus more on industrialization exemplified by the mega-projects, and those focused on sustainable development, exemplified by Projeto Castanha-do-Brasil. Several Amazonian states, with the support of social movements and NGOs have sought to create their own models for economic growth in the Amazon placing an emphasis on sustainable growth. There is little question that an economic development model should exist in the Amazon, the only question is can sustainable development be that model?

If the Amazon continues to be developed in the same fashion that it has been developed since the $19^{\text {th }}$ century, then there is little hope that the environmental characteristics that make it unique will last beyond the $21^{\text {st }}$ century. Deforestation caused by predatory logging is the most pressing problem that the Amazon faces and sustainable development may be the answer. Sustainable development embraces a wide range of programs that seek to bring about economic growth without damaging the environment. In most sustainable development projects economic growth is not as rapid as it would be if another sort of development program were initiated. However, with sustainable development, economic growth is maintained throughout the lifetime of the project, providing a stable income for residents, whereas other development models create a cycle of boom and bust as exemplified by predatory logging.

One example of sustainable development in the Amazon, Projeto CastanhadoBrasil, has brought about tremendous economic gains. Those involved in the program have increased their income in a variety of ways, the most important of which are removing the middleman, creating product verticalization, and increasing the market for brazil-nuts. Additionally, the program has brought about a number of improvements in the day-to-day lives of the participating families. Increased citizenship, increased social inclusion, and electrification, are just some of the benefits that are not purely economic benefits but definitely contribute towards improving the standard of living.

Projeto Castanha-do-Brasil has been able to achieve these results while at the same time protecting the environment and reaching citizens that may not have reaped the benefits of a mega-project. What is perhaps even more impressive is that Projeto Castanha-do-Brasil has achieved its success without federal assistance. One main criticism of sustainable development projects is that there cannot benefit a large number of people. However, if the federal government devoted the resources from the mega-project model to the sustainable development model, sustainable development could provide the answer of how to develop the Amazon on a large scale while still protecting the forest and making sustainable development a viable solution. 